\title{
Physiological and Immunological Responses in Giant California Sea Cucumbers (Parastichopus californicus) Exposed to Aquaculture-related Stress
}

\author{
Regina Shannon, Elliott Blumenthal, Ahmed Mustafa*
}

Department of Biology, Indiana University-Purdue University Fort Wayne, USA

Copyright (C) 2015 by authors, all rights reserved. Authors agree that this article remains permanently open access under the terms of the Creative Commons Attribution License 4.0 International License

\begin{abstract}
Sea cucumbers are a valuable resource both for food and the production of nutraceuticals and pharmaceuticals, and as a result, the market for the giant California sea cucumber, Parastichopus californicus, has greatly increased, resulting in the establishment of fisheries along the west coast of North America. The sea cucumber industry is poorly regulated, and the fisheries are not believed to be sustainable, so there is interest in promoting the intensive aquaculture of this species. Since aquaculture conditions can cause stress to animals, which makes them more susceptible to disease, it is important to determine the stress susceptibility of sea cucumbers to two potential stresses, handling and low salinity. In order to study the impact of these stressors, a variety of physiological and immunological assays were done on the coelomic fluid of giant California sea cucumbers. Assays included total and differential cell counts, coelomic fluid protein, phagocytic capacity, lytic activity, and respiratory burst activity. Our results indicated that there were few significant differences from the control, and no differences in parameters analyzing immune function. These results indicate that the giant California sea cucumber is likely to be productive in an aquaculture environment, and the culture of this species should be encouraged.
\end{abstract}

Keywords Sea Cucumber, Aquaculture, Stress, Immune Response

\section{Introduction}

The giant California sea cucumber (Parastichopus californicus), is found off the west coast of North America from Alaska through Mexico. It is a one of the largest known species of sea cucumbers and can grow to a length of 20 inches $(50 \mathrm{~cm})$, and is an important food item for human consumption. This has led to a overfishing of many of the commercial populations, and this is leading to a rapid decline in the sustainability of these fisheries and the sea cucumber population [1]. Despite this, the demand for sea cucumber is only increasing, particularly in China, and this has allowed for the establishment of a market for the North American species $P$. californicus. This has led to the development of sea cucumber fisheries in British Columbia, Alaska, and down the west coast. Though currently $P$. californicus is being harvested at a sustainable rate [2], as the market for it increases, particularly overseas, it will be increasingly vulnerable to overfishing [3]. Due to the problems associated with fisheries, interest has been turning to aquaculture, and though the Japanese sea cucumber has been successfully raised in aquaculture for decades, little is known about the biology and requirements of the giant California sea cucumber [4], and as yet no intensive or pond culture systems have been established for it. In addition to being a valuable food item, sea cucumbers are generating much interest as a source of pharmaceuticals, and nutraceuticals, making them of interest to research facilities. Some of the current research being done includes the treatment of arthritis and connective tissue disorders, utilizing mucopolysaccharides and chondroitins derived from sea cucumbers. It has been discovered that that sea cucumbers have high amounts of arachidonic acid, which is known to promote wound healing, and they have large amounts of eicosapentaenoic acid (EPA) and decoshexaenoic acid (DHA), which are known to reduce the incidence of coronary heart disease and some cancers $[1,5]$. Chondroitin sulfates isolated from sea cucumbers have been found to have antiviral properties, and saponins, which were formerly thought to be unique to plants, have also been isolated and have been found to have a wide range of effects, including anticancer and antitumor properties, as well as hemolytic and cytostatic effects $[1,5]$. Of particular interest is recent work based in Japan that has used molecules derived from sea cucumbers to regenerate nerve cells in rats [1]. As is an increasingly important food source, and a source of 
compounds potentially useful in biomedicine [3], it is an ideal animal for intensive culturing. However, animals in intensive aquaculture conditions are faced with a variety of factors that can cause stress, which can potentially lead to decreased growth, loss of immune function which increases susceptibility to disease, and increased mortality. Disease is particularly problematic as there is no current effective treatment for disease in invertebrates, so mortality rates can be very high, causing immense financial loss to the aquaculturists [6]. We examine in our research whether $P$. californicus experiences stress in conditions that occur in aquaculture by examining the cellular responses. Though research has been done on the growth of the sea cucumber in kept in culture with other species, to the best of our knowledge, this is the first research to examine the cellular responses of California sea cucumbers kept in intensive aquaculture conditions.

Sea cucumbers are believed to have an innate but not an adaptive immune system. The majority of this immunity is based in the cells circulating in the coelomic cavity, referred to as coelomocytes [7]. These cells are responsible for response to injury and infection, allograft rejection, and the clearance of bacteria and foreign particles [7]. Though not all of the cell types and functions are known, in sea cucumbers, the primary cell type consists of lymphocytes, which are small, spherule-shaped cells that make of the majority of the cell population. These cells are thought to be precursor cells of the other cell types [7]. The phagocytic cells generally have round or irregular shapes, and are larger than lymphocytes. As their name suggests, they are responsible for phagocytic activity, and it appears that the phagocytic cells of sea cucumber contain lysosomal enzymes that play an important role in the degradation of foreign particles [8]. Spherule cells are the least abundant of the primary cell types, and they are also the largest cell type, and have a granular appearance [7], but there is very little known about their function. There are a few other cells types, but their abundance is so low that they have not been included in this study.

\section{Materials and Methods}

\subsection{Experimental Design}

Giant California sea cucumbers (Parastichopus californicus) were purchased from Bodega Marine Laboratory (Bodega Bay, CA). Before distribution to treatment groups, all animals were acclimated in $34 \mathrm{ppt}$ artificial seawater, and kept in 40 gallon tanks that were filtered and oxygenated by Fluval Aqua Clear Power Filters. All animals were supplied with live sand (Nature's Ocean ${ }^{B}$ BIO-ACTIV LIVE ${ }^{\circledR}$ ARAGONITE). All treatment groups were maintained at temperature at $13.1 \pm 1{ }^{\circ} \mathrm{C}, \mathrm{DO}$ at $8.5 \pm 1$, $\mathrm{pH}$ at $8.3 \pm 1$, and a 12 hour light 12 hour dark light cycle. After acclimation, animals were divided into salinity stress
( $28 \mathrm{ppt}$ ), handling stress ( $34 \mathrm{ppt}$, handling for $\sim 2$ minutes per animal; 3 times daily), and control (34 ppt and no handling). Salinity stress group animals were acclimated to $28 \mathrm{ppt}$ by being exposed to dropping salinity levels over a course of 24 hours. Treatment conditions were maintained for 72 hours, and sea cucumbers were sampled after the treatment period. The immunological and physiological responses of the sea cucumbers were determined by total and differential cell count, coelomic fluid protein, phagocytic capacity, respiratory burst assay, and lytic activity. Coelomic fluid was obtained by piercing the body wall using a 22 gauge needle and syringe [9] and withdrawing in an equal volume with ice-cold anticoagulant for phagocytic capacity, respiratory burst, and cell counting. An additional volume was collected without anticoagulant for determination of total coelomic fluid protein and lytic activity.

\subsection{Total and Differential Cell Count}

Cells obtained with an equal volume of anticoagulant were counted in $20 \mu \mathrm{l}$ aliquots via hemocytometer for total and differential cell counts.

\subsection{Total Protein Content}

A handheld refractometer (VEEGEE Scientific Inc. Kirkland, WA) was used to measure coelomic fluid protein content. The refractometer was calibrated to zero by placing a drop of distilled water on the surface of the prism and adjusting the focus and closing the day-light plate. After calibration, two drops of coelomic fluid plasma obtained from hematocrit capillary tubes were placed on the prism, and the protein content was read through the eyepiece, and recorded as milligrams of protein per milliliters of coelomic fluid.

\section{Phagocytic Capacity}

To determine phagocytic capacity, for each sea cucumber, $50 \mu \mathrm{l}$ of sample coelomic fluid with anticoagulant was added in duplicate on Esco Fluro glass slides [10] and incubated at room temperature for 90 minutes. After incubation, $50 \mu \mathrm{l}$ of formalin killed bacteria (Bacillus megaterium) was added and allowed to incubate for 60 minutes. The slides were then carefully washed with PBS, and after air drying, fixed in methanol. After drying, slides were stained with Giemsa-Wright stain. At least 50 coelomocytes were counted at $100 \mathrm{x}$ magnification per slide, and phagocytic capacity was determined by the percentage of coelomocytes containing 3 or more bacteria [11].

\subsection{Respiratory Burst Activity}

To determine coelomocyte respiratory burst activity, $100 \mu \mathrm{l}$ of coelomic fluid with anticoagulant and $100 \mu \mathrm{l}$ of formalin killed bacteria were added in triplicate to a 96-well plate and incubated at room temperature for 30 minutes. The bacteria was then removed, the wells were rinsed three times 
with $100 \mu \mathrm{l}$ PBS, and $100 \mu \mathrm{l}$ of NBT solution was added and allowed to incubated for 30 minutes and removed. The wells were then fixed with absolute methanol, and rinsed three times with $70 \%$ methanol. Subsequently, $120 \mu \mathrm{l}$ of KOH and $140 \mu 1$ DMSO were added to dissolve the DBT diforazon precipitate. Plates were then read in a spectrophotometer at $600 \mathrm{~nm}$ for comparison of absorbance [12]

\subsection{Lytic Activity}

The lysozyme turbidity assay was performed by adding $0.985 \mathrm{mg}$ of Micrococcus lysodeikticus for the bacterial challenge, $4.925 \mathrm{ml}$ of sodium phosphate buffer, and $5 \mathrm{mls}$ of sea cucumber serum to a cuvette. The serum was obtained by allowing the volume of coelomic fluid without any anti-coagulant to sit for at least four hours to allow complete clotting and separation of the cells and serum. The decrease in light absorbance due to lytic activity from 0 to 5 minutes was measured at $530 \mathrm{~nm}$ using a spectrophotometer [13].

\subsection{Data Analysis}

The data obtained was analyzed using SigmaPlot ${ }^{\circledR}$ 12.5, 2013. The means and standard errors of the means were calculated for each assay by one way analysis of variance (ANOVA), and differences were considered significant when $\mathrm{P}<0.05$. Tukey's comparison of multiple means test was performed post-ANOVA to determine any differences between groups. The graphs included present means \pm standard errors of the means.

\section{Results}

The total cell count showed significantly higher numbers in the handling group than was present in the control group, but no significant difference between the low salinity exposed and control group (Fig. 1). There was no significant difference between groups for any of the differential cell counts (Figs. 2, 3, 4). The total coelomic fluid protein content was significantly lower in both the low salinity exposed and handling groups than it was in the control group (Fig. 5). There was also no significant difference between the groups for phagocytic capacity, respiratory burst, and lytic activity, though lytic activity was slightly increased in the low salinity exposed and handling groups (Figs. 6, 7, 8).

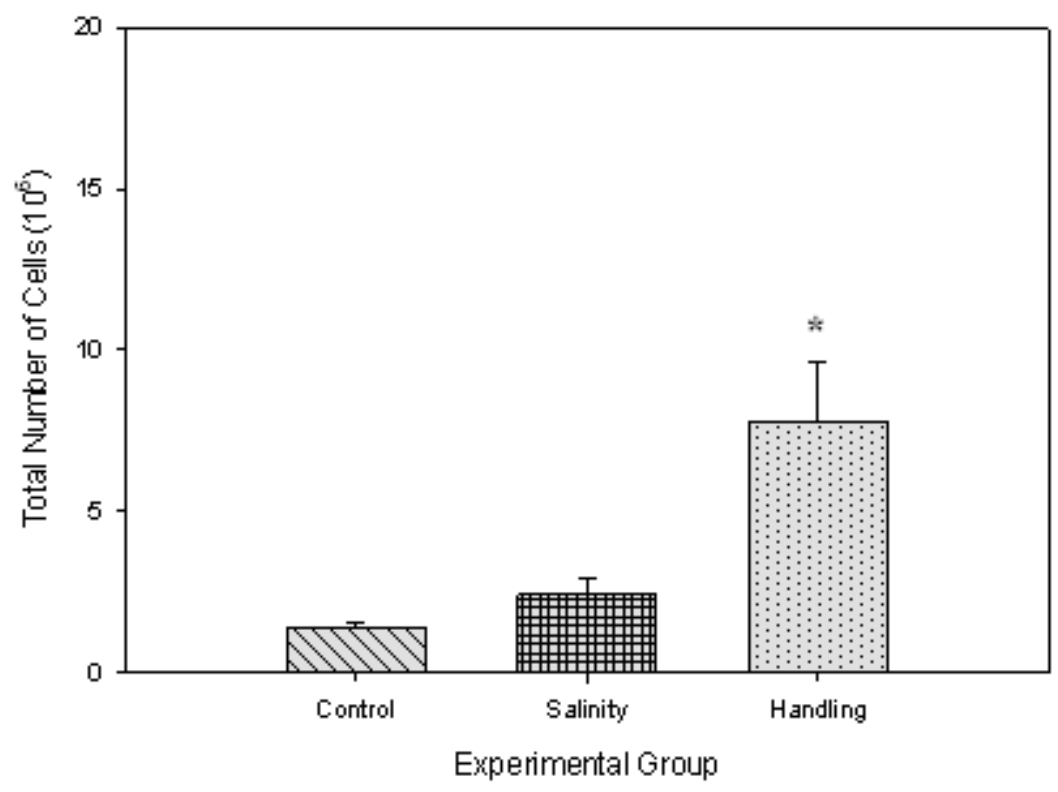

Figure 1. Number of total cells in three different treatment groups. * Significantly different $(\mathrm{P}<0.05)$. 


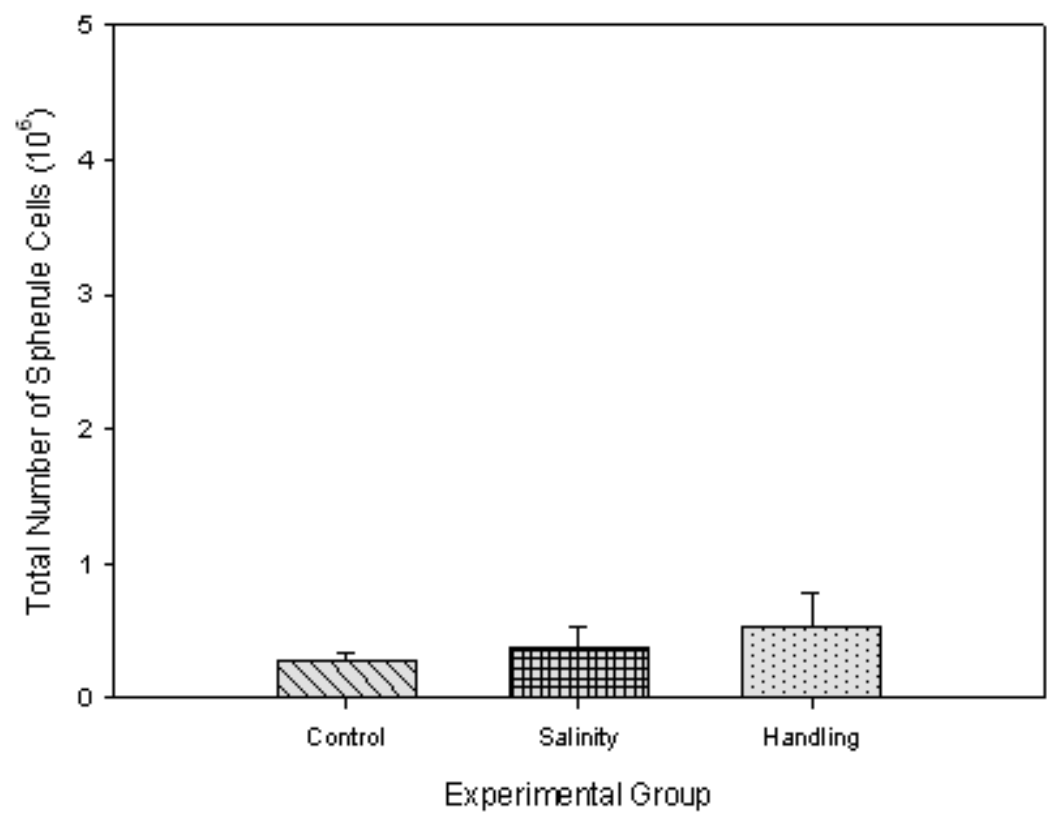

Figure 2. Number of spherule cells in three different treatment groups

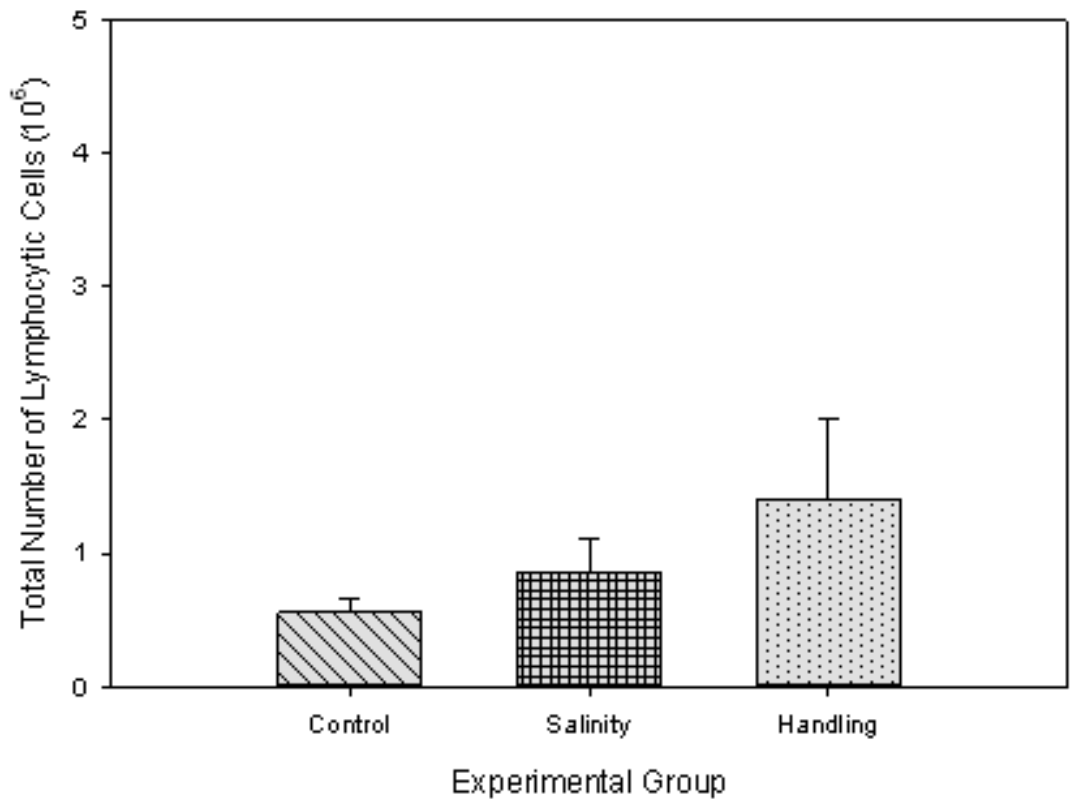

Figure 3. Number of lymphocytic cells in three different treatment groups. 


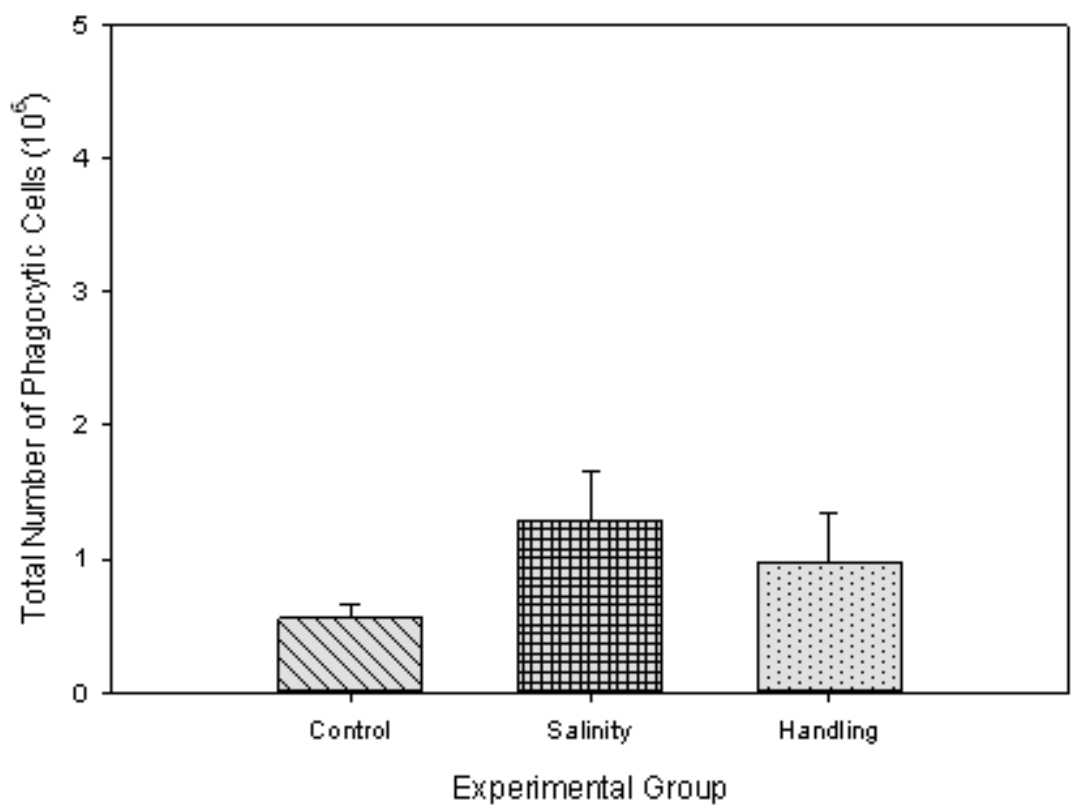

Figure 4. Number of phagocytic cells in three different treatment groups.

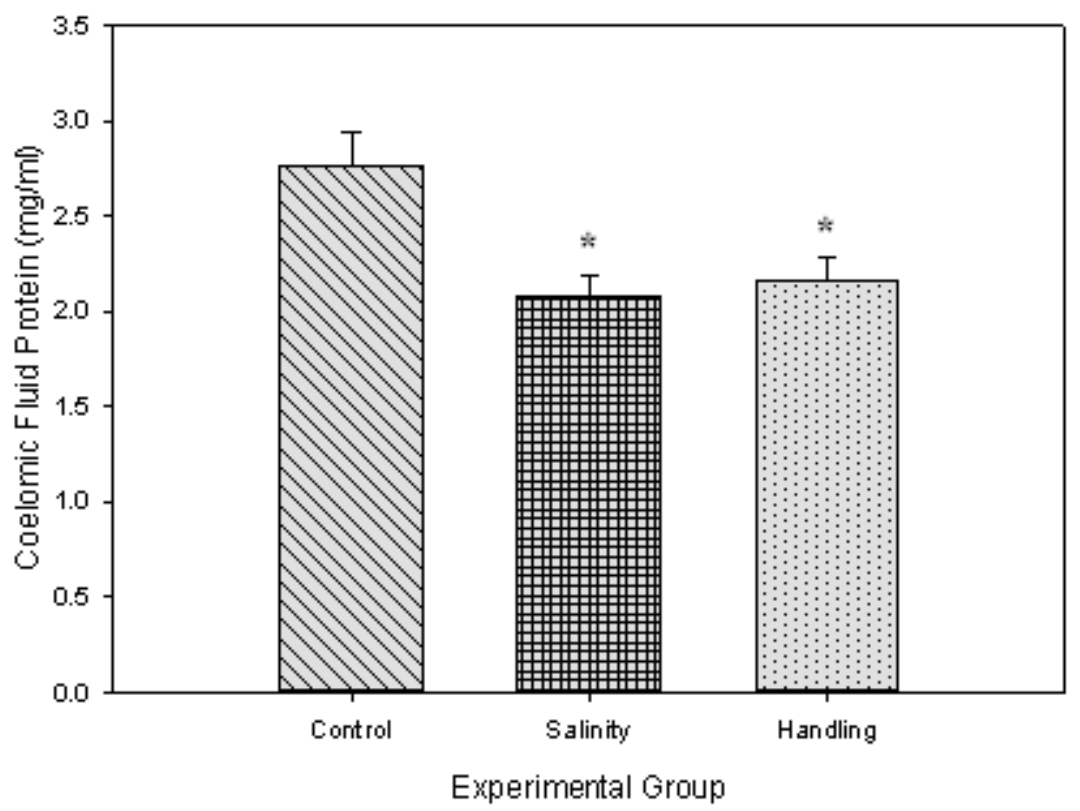

Figure 5. Total protein contents in three different treatment groups. * Significantly different $(\mathrm{P}<0.05)$. 


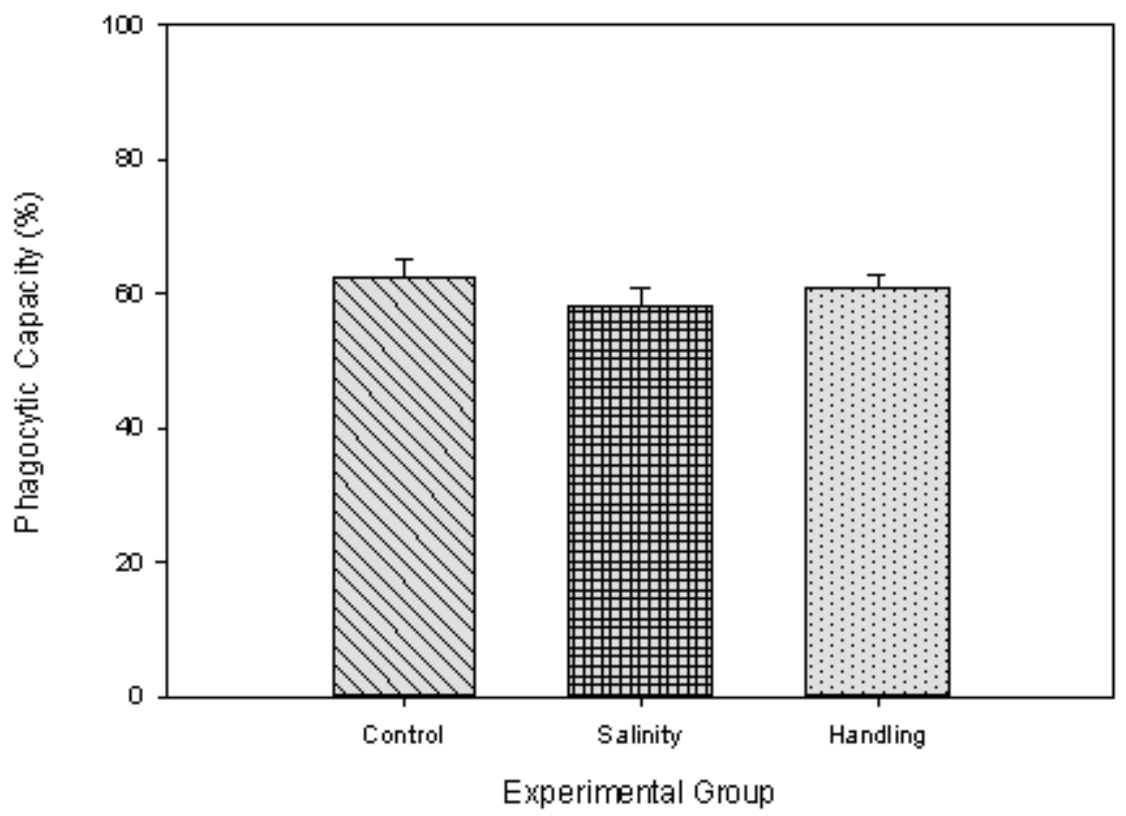

Figure 6. Phagocytic capacity of cells in three different treatment groups. * Significantly different $(\mathrm{P}<0.05)$.

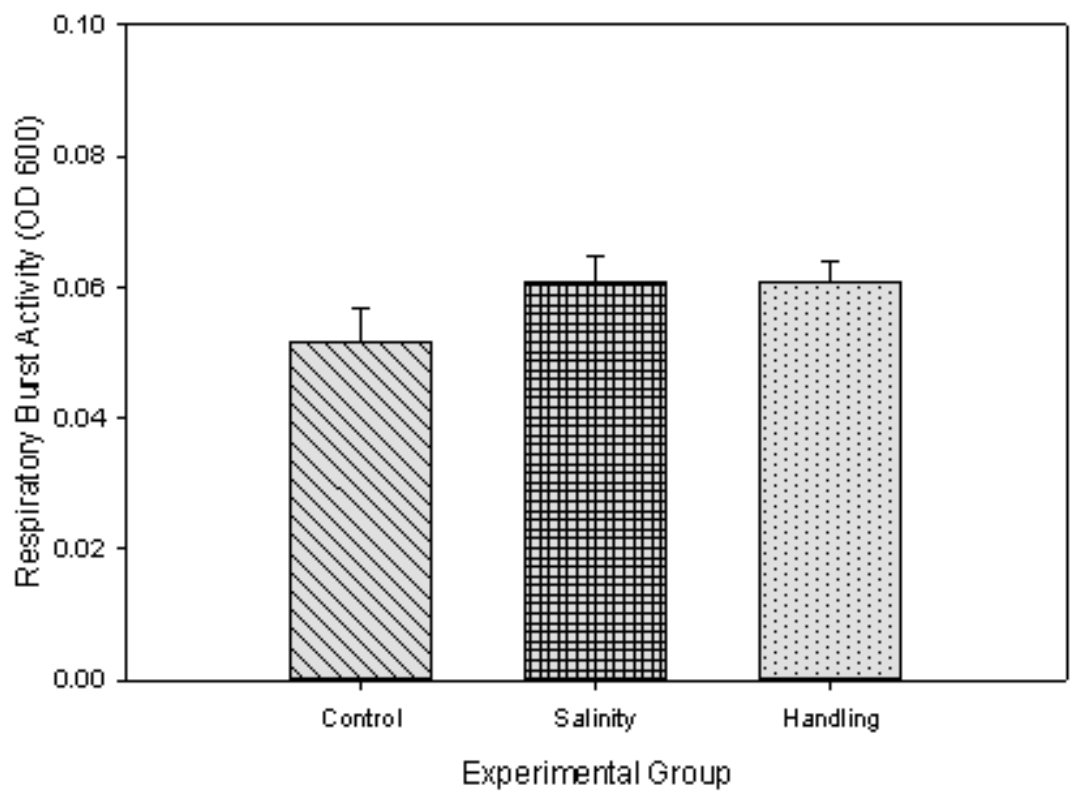

Figure 7. Respiratory burst activity of cells in three different treatment groups. 


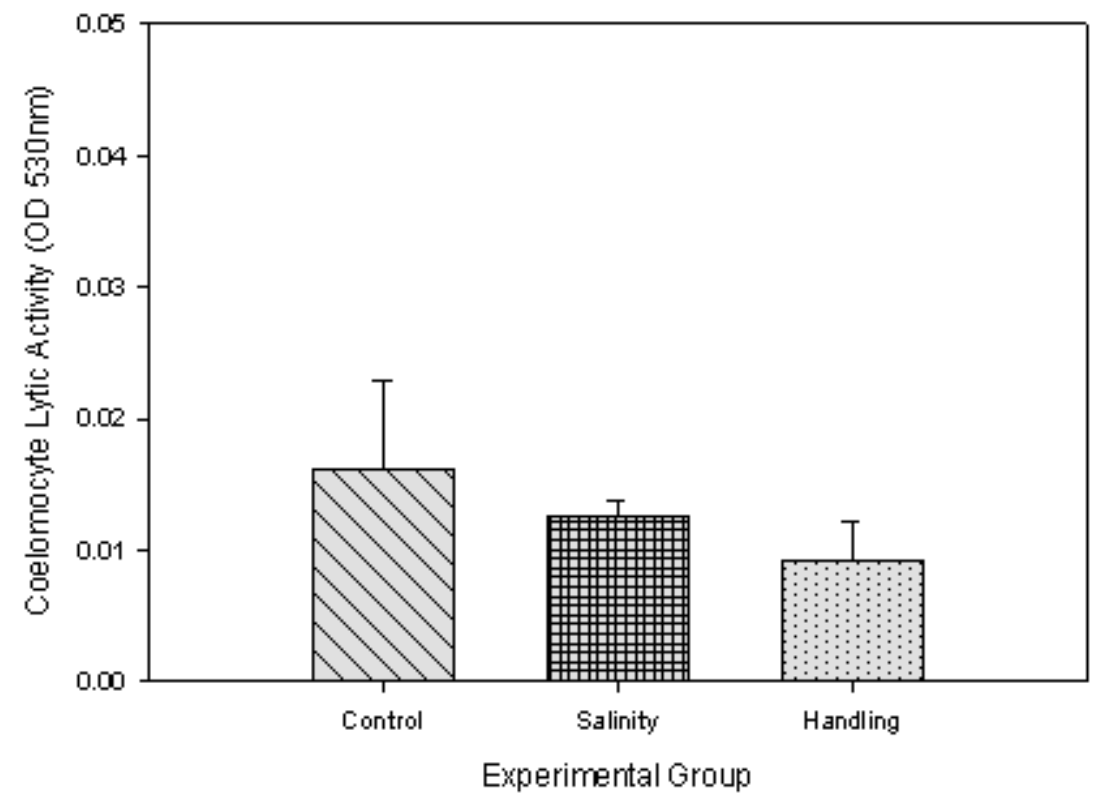

Figure 8. Lytic activity in three different treatment groups.

\section{Discussion}

P. californicus appears to have no significant stress responses to either low salinity or handling. A significantly greater number of cells was observed in the handling group as compared to the control group which is most likely due to the high number of lymphocytic cells observed for that group. In the spherule cell and phagocytic cell counts, while there is some variation between groups, there are no significant differences observed. A significantly lower amount of coelomic fluid protein was observed in the two stress groups, and based on previous research, some proteins, such as lectins, will change under certain conditions $[14,15]$. It is particularly interesting to note that while there were increases in cell numbers in the stress groups, the immunological results, phagocytosis, respiratory burst, and lytic activity, indicate that there has been little impact on the immune function of the sea cucumbers Even if the animals are experiencing some stress, as evidenced by the total cell count data, it is apparent that it is not enough to make them more susceptible to disease, as there is no significant difference in the immune function among groups. This would imply that this particular species is an ideal candidate for aquaculture, as it is appears to be resistant to stresses inherent in an aquaculture or research facility. It would be a valuable study to repeat the experiment presented here with the addition of nutraceuticals to see if the cell increases observed here would be reduced, and to see if the immune function could be enhanced. Other areas for further research would include studies comparing the quality of cultured sea cucumbers to wild-caught cucumbers as a way of promoting the active culture of sea cucumbers in the United States. Critical to this would be studies on the best ways to successfully raise giant California sea cucumbers, as currently there is very little information known about their biological requirements [4]. Also beneficial would be longer term studies that can analyze these responses at a variety of time points to examine any changes. Research could also focus on comparative studies of different sea cucumber species to see which are the most valuable for pharmaceutical work.

\section{Acknowledgements}

Many thanks to Karl Menard of Bodega Marine Laboratory for his assistance in collecting the sea urchins and sea cucumbers used for this study. Thanks also to Arlis LaMaster for her technical assistance, and to Heidi Nissely, Destin Furnas, and Grayson Ostemeyer for their cheerful laboratory assistance.

\section{REFERENCES}

[1] S. Bordbar, F. Anwar, N. Saari. High-value components and bioactives from sea cucumbers for functional foods-a review. (Review article), Marine Drugs, Vol. 9, 1761-1805, 2011.

[2] W. Hajas, C. Hand, N. Duprey, J. Lochead, J. Deault. Using production models with new and developing fisheries: A case study using the sea cucumber Parastichopus californicus British Columbia, Canada, Fisheries Research, Vol. 110, 421-434, 2011.

[3] P. J. Betchtel, A. C. Oliveira, N. Demir, S. Smiley. Chemical composition of the giant red sea cucumber, Parastichopus californicus, commercially harvested in Alaska, Food Science and Nutrition, Vol. 1, 63-73, 2013.

[4] A. K. Azad, R. S. McKinley, I. P. Forster, C. M. Pearce. The 
California sea cucumber-A potential candidate for aquaculture, World Aquaculture, Vol 45, 43-48, 2014.

[5] P. L. Kiew, M. M. Don. Jewel of the seabed: sea cucumbers as nutritional and drug candidates, International Journal of Food Sciences and Nutrition, Vol. 63, 616-636, 2012.

[6] J. D. Loy, C. Bartholomay, D. L. Harris, E. Scura, I. Kamrud. United States Patent, 2014. Patent No. 2 US 8,828,961 B2.

[7] F. Ramirez-Gomez, F. Aponte-Rivera, L. Mendezz-Castaner, J. E. Garcia-Arraras. Changes in holothurian coelomocyte populations following immune stimulation with different molecular patterns, Fish and Shellfish Immunology, Vol. 29, 175-185, 2010.

[8] P. S. Gross, W. Z. Al-Sharif, L. A. Clow, L. C. Smith. Echinoderm immunity and the evolution of the complement system, Developmental and Comparative Immunology, Vol. 23, 429-442, 1999.

[9] A. Mustafa, S. A. Hayat, P. Quarrar. Stress modulated physiological responses in Nile tilapia, Oreochromisniloticus, treated with non-ascorbic acid supplemented feed, Advances in Zoology and Botany, Vol. 1, No. 2, 39-45, 2013.

[10] A. Mustafa, C. MacWilliams, N. Fernandez, K. Matchett, G. A. Conboy, Burka. "Effects of Sea Lice (Lepeophtheirussalmonis Kroyer, 1837) infestation on macrophage functions in Atlantic salmon (Salmosalar L.), Fish and Shellfish Immunology, Vol. 10, 47-59, 2000

[11] F-S. Chia, J. Xing. Echinoderm Coelomocytes (Review Article), Zoological Studies, Vol. 35, 231-254, 1996.

[12] S-T. Yeh, C-H. Liu, J-C. Chen. Effect of copper sulfate on the immune response and susceptibility to Vibrio alginolyticus in the white shrimp Litopenaeus vannamei, Fish and Shellfish Immunology, Vol.17, 437-446, 2004.

[13] A. E. Ellis. Lysozyme Assays,.J. S. Stolen, T.C. Fletcher, D. P. Anderson, B. S. Roberson, W. B. van Muiswinkel (Editors), Techniques in Fish Immunology. SOS Publications, Fair Haven, NJ USA, 1990.

[14] Y. Dong, J. Tingting, S. Dong. Stress responses to rapid temperature changes of the juvenile sea cucumber (Apostichopus japonicas Selenka), Journal of Ocean University of China, Vol. 6, 275-280, 2007.

[15] F. Wang, H. Yang, F. Geo, G. Liu. Effects of acute temperature or salinity stress on the immune response in sea cucumber, Apostichopus japonicas, Comparative Biochemistry and Physiology, Part A. Vol. 151, 491-498, 2008. 